\title{
Short-term grazing behavior of cattle under indoor housing for a new-bred tetraploid ruzigrass (Brachiaria ruziziensis Germain et Everard)
}

\author{
Genki Ishigaki', Pattama Nitthaisong ${ }^{2}$, Yogi Sidik Prasojo ${ }^{3}$, Ikuo Kobayashi', Kiichi Fukuyama', \\ Mohammad Mijanur Rahman ${ }^{4}$, and Ryo Akashï ${ }^{2, *}$
}

\author{
* Corresponding Author: Ryo Akashi \\ Tel: +81-985-58-7257, Fax: +81-985-58-7761, \\ E-mail: rakashi@cc.miyazaki-u.ac.jp \\ ${ }^{1}$ Sumiyoshi Livestock Science Station, Field Science \\ Education Research Center, Faculty of Agriculture, \\ University of Miyazaki, Miyazaki 880-0121, Japan \\ 2 Faculty of Agriculture, University of Miyazaki, \\ Miyazaki 8892192, Japan \\ ${ }^{3}$ Interdisciplinary Graduate School of Agriculture \\ and Engineering, University of Miyazaki, Miyazaki \\ 8892192, Japan \\ ${ }^{4}$ Faculty of Agro Based Industry, University Malaysia \\ Kelantan, 17600 Jeli, Kelantan, Malaysia \\ ORCID \\ Genki Ishigaki \\ https://orcid.org/0000-0002-8716-6702 \\ Pattama Nitthaisong \\ https://orcid.org/0000-0001-6674-9696 \\ Yogi Sidik Prasojo \\ https://orcid.org/0000-0001-9724-5765 \\ Ikuo Kobayashi \\ https://orcid.org/0000-0002-0687-381X \\ Kiichi Fukuyama \\ https://orcid.org/0000-0002-1192-9208 \\ Mohammad Mijanur Rahman \\ https://orcid.org/0000-0002-6244-7129 \\ Ryo Akashi \\ https://orcid.org/0000-0002-5651-8285
}

Submitted Jul 21, 2017; Revised Sept 8, 2017; Accepted Oct 9, 2017
Objective: The preference evaluation of cattle is an important factor for estimation and improvement of the grazing amounts of newly introduced or bred grasses or cultivars in barn. This study was performed to assess the grazing behavior (the amount of grazing and/or the grazing speed) of cattle as indirect method using newly bred Brachiaria ruziziensis tetraploid strain 'OKI-1'(BR) hay as treatment group and Cloris gayana 'Callide' (CG) hay as control group. It also compared the feasibility of using behavioral differences between two groups as one criteria for evaluating preference by Japanese black cattle in barn.

Methods: Three experiments were carried out using 12 growing Japanese Black cattle including 6 males and 6 females. In each experiment, the four Japanese Black cattle ( 2 males and 2 females) were placed in separated stall and allowed to graze BR and CG in manger that was separated into two portions for about $30 \mathrm{~min}$. The position and behavior of the cattle were recorded, and weighed the residual of each gay at 15 and 30 minutes after experiment start. Results: The BR was superior to CG in chemical composition such as protein, fibers and non-fibrous carbohydrate. The cattle, over all, tended to prefer BR over CG in the first half 15 minutes in terms of the time spent and amount of grazing. Additionally, growing cattle exhibited neophilia for BR bred newly.

Conclusion: These findings indicated the current approach could be applied for one of criteria to evaluate the preference of hay by Japanese black cattle under indoor housing environment.

Keywords: Brachiaria ruziziensis; Chloris gayana; Grazing Behavior; Indoor Housing; Japanese Black Cattle; Preference

\section{INTRODUCTION}

Brachiaria is one of tropical forage grasses native to the African tropical savannas, and some Brachiaria species such as B. brizantha, B. decumbens, B. ruziziensis and B. humidicola have been introduced into temperate warm region (Kyushu and the Okinawa islands) in Japan and were reported to have produced high dry matter yield in some of these species [1]. Though these species exhibited good performance, it is difficult to conduct a Brachiaria breeding with a traditional hybridization approach because almost all species are predominantly facultative apomictic polyploids [2]. Therefore, tetraploid sexual ruzigrass was produced by in vitro-colchicine treatment with multiple-shoot clumps or seedlings for the Brachiaria breeding program as a source of sexuality [3]. Subsequently, [4] performed recurrent selection for high seed yield components in a population of a newly-bred sexual tetraploid ruzigrass (Brachiaria ruziziensis) strains in Japan. In order to expand the newly-raised cultivars on 
a commercial basis in the future, it is essential to evaluate the preference of cattle.

Previous studies of preference or palatability evaluation in barn have been reported in some grasses $[5,6]$. However, there is no direct method to evaluate the preference under indoor housing environment. Therefore, it is needed to study the amount of grazing and/or the grazing speed as indirect method for preference evaluation of newly introduced or bred grasses or cultivars. The cattle preference at early age defined as that the cattle takes a strong interest in a new object for feeding performance when the cattle start to perform grazing in grassland or barn. Thus, the present study was carried out in order to investigate the grazing behavior by cattle at early age using newly bred tetraploid ruzigrass strain, and to assess the feasibility of the behavior as one of criteria for preference evaluation in Japanese black cattle under indoor housing environment.

\section{MATERIALS AND METHODS}

\section{Experiment site}

Three preference experiments were carried out at the Sumiyoshi Livestock Science Station $\left(39^{\circ} 59^{\prime} \mathrm{N}, 131^{\circ} 28^{\prime}\right.$ E, elevation of $12 \mathrm{~m}$ above sea level), Faculty of Agriculture, University of Miyazaki, Southern Kyushu, Japan. The soil type was characterized as sandy soil. Experiments 1, 2, and 3 were conducted at 5, 12, and 19 October 2015, respectively, and each experiment was lasted for 4 days.

\section{Plant materials}

Two kinds of warm-season grasses, Chloris gayana 'Callide' (CG) and Brachiaria ruziziensis, tetraploid strains 'OKI-1' (BR) were studied. The tetraploid ruzigrass strain 'OKI-1' was F5 generation selected based on seed yield and fertility from tetraploid ruzigrass F2 generation [3] in previous study [4].

\section{Establishment and management of plant material}

Seeds of two grasses were planted at a seeding rate of $30 \mathrm{~kg} / \mathrm{ha}$ for each on 27 May 2015. The basal fertilizer consisting of nitrogen $(13 \% \mathrm{~N})$, double super phosphate $\left(13 \% \mathrm{P}_{2} \mathrm{O}_{5}\right)$ and potassium chloride $\left(13 \% \mathrm{~K}_{2} \mathrm{O}\right)$ was applied at a rate of 40,34 , and $29 \mathrm{~kg} / \mathrm{ha}$, respectively. Manure was applied (containing $2.5 \% \mathrm{~N}, 4.0 \% \mathrm{P}_{2} \mathrm{O}_{5}$ and $2.1 \% \mathrm{~K}_{2} \mathrm{O}$ ) at a rate of $10 \mathrm{t} / \mathrm{ha}$. Following the first cutting, additional applications for $\mathrm{N}, \mathrm{P}_{2} \mathrm{O}_{5}$ and $\mathrm{K}_{2} \mathrm{O}$ were applied at the same rate. Agronomic traits were investigated, and plants were cut $10 \mathrm{~cm}$ above ground level on the 19 August for first cutting (after 84 days from sowing date), and 7 October for second cutting (after 49 days from first cutting date). Measurements for ten randomly selected grasses were collected; plant height was measured using a meter stick at the day of cutting for each harvest. Tiller number, stem diameter, leaf blade width and leaf blade length were also determined for plants in the first and second cuttings. Cutting plant materials were sun-dried as hay for animal experiment. Sampling of plant materials was dried in an oven at $60^{\circ} \mathrm{C}$ for 48 hours and ground to pass a 1-mm sieve for chemical analysis. Total ash was determined by igniting at $550^{\circ} \mathrm{C}$ for 3 hours. Crude protein $(\mathrm{CP})$ was estimated as $6.25 \times \mathrm{N}$ that total $\mathrm{N}$ was determined by Kjeldahl's analysis. Neutral detergent insoluble protein (NDICP) was determined by analyzing neutral detergent fiber (NDF) residues for Kjeldahl's nitrogen [7]. Ether extract and crude fiber (CF) were determined according to AOAC [8], NDF, acid detergent fiber (ADF), and acid detergent lignin were determined by the method of detergent analysis [9]. Nitrogen-free extract was estimated by subtracting CP, NDF, ether extract, crude ash, and adding NDICP as correction.

\section{Animals}

Twelve Japanese Black cattle ( 6 males and 6 females) were used for three experiments. Four animals ( 2 males and 2 females) were used for each experiment. The used animals were in growing age, and the body weight of the animal was $271 \pm 9.4 \mathrm{~kg}$ (mean \pm standard error [SE]). The cattle were raised with hayfed mainly and concentrate-fed at the amount to meet the nutrient requirement. The cattle were tamed and accustomed to the experimental methods. The cattle had experience for grazing CG, but no experience for grazing BR. The $0.5 \mathrm{~kg}$ of CG hay and BR hay were set in a manger (size: $54 \times 260 \times 37$ $\mathrm{cm}$ ) separated two portions, respectively. Each manger was obstructed by a black sheet (size: $82 \times 260 \mathrm{~cm}$ ) until the experiment start (Figure 1). In each experiment, the four individual cattle were allowed to graze a hay fed in manger area at 09.00 JST (the beginning of daily grazing period) for about $30 \mathrm{~min}$ for four consecutive days. The position (CG or BR) and behavior (grazing or non-grazing [e.g. resting]) of the animals were recorded by digital video camera and weighed the re-

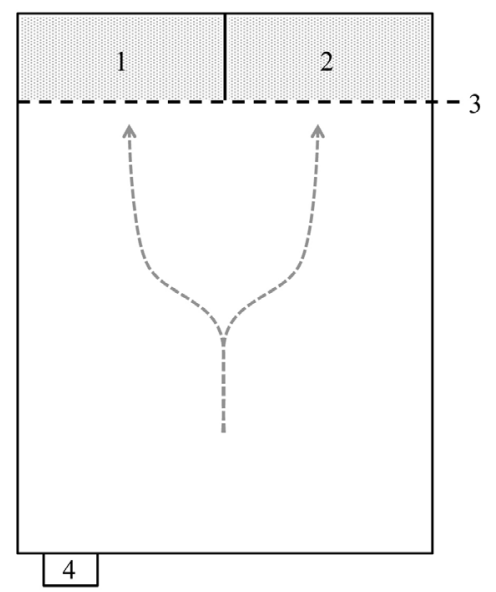

Figure 1. Experimental plot image; 1, 2: Ruzigrass tetraploid strain or rhodesgrass. The position of two grasses were replaced everyday. 3: Black sheet were set until when the experiment started. 4: Water cup point. 
sidual of each hay at 15 and 30 minutes after experiment start. The location of each hay was exchanged right and left every day during experiments. After experimental hay feeding for 30 minutes, animals were fed restricted feeding with Guinea grass (Panicum maximum) hay and concentrate as farm feeding practice.

\section{Statistical analysis}

The means of the measured morphological traits and analyzed chemical composition were evaluated by the $t$-test between CG and BR for each experiment. Percentage data were transformed to angular figures [10]. Performance of preference for CG and BR was assessed based on the $t$-test as the bias from the random choice, that is the area proportion of the two grasses (0.5:0.5). Relationship between time spent grazing BR was assessed by calculation correlation coefficient. All statistical analyses were carried out with program $\mathrm{R}$ version 3.1.1 [11].

\section{RESULTS AND DISCUSSION}

The agronomic traits and dry matter yield of CG and BR are summarized in Table 1. The plant length of BR tended to be shorter than rhodes grass $(\mathrm{p}<0.05)$. Both grass species differed $(\mathrm{p}<0.05)$ in stem diameter, leaf blade width and leaf blade length. However, BR had thicker stems, wider leaf blade and shorter leaf blade length than CG. These differences in morphological traits could contribute to increase total fresh matter yield. Indeed, the fresh matter yield was significantly higher $(\mathrm{p}<0.05)$ in BR $(37.17 \mathrm{t} / \mathrm{ha})$ than CG $(25.83 \mathrm{t} / \mathrm{ha})$. Despite the higher fresh matter yield in BR, dry matter yield was not differed ( $p>0.05$ ) (5.93 vs $6.05 \mathrm{t} / \mathrm{ha}$ ) between BR and CG, respectively. It seemed that $\mathrm{BR}$ has higher moisture content than
CG. High moisture content improves palatability that causes the forage to taste sweet, sour, or salty [12].

Producing quality forage such as palatability, intake, digestibility and nutrient content are essential because it directly affects animal performance and economic return [12]. Table 2 summarizes the chemical composition of CG and BR. The $\mathrm{CP}$ content of $\mathrm{BR}(12.2 \mathrm{~g} / \mathrm{kg})$ was significantly $(\mathrm{p}<0.05)$ higher than CG $(10.5 \mathrm{~g} / \mathrm{kg})$. Notable, BR showed a lower content of $\operatorname{NDCIP}(\mathrm{p}<0.05)(29.1 \mathrm{~g} \mathrm{CP} / \mathrm{kg})$ than CG $(43.3 \mathrm{~g} \mathrm{CP} / \mathrm{kg})$, which might been induced by a lower content of NDF $(63.0 \mathrm{~g} / \mathrm{kg})$ and $\operatorname{ADF}(35.1 \mathrm{~g} / \mathrm{kg})$ that those of CG (NDF, $67.6 \mathrm{~g} / \mathrm{kg}$; ADF, 38.8 $\mathrm{g} / \mathrm{kg}$ ). The non-fibrous carbohydrate (NFC) content of BR $(14.5 \mathrm{~g} / \mathrm{kg})$ was higher $(\mathrm{p}<0.05)$ than that of CG $(12.0 \mathrm{~g} / \mathrm{kg})$. Considering these chemical compositions of both grasses, the forage quality in BR was overall superior to $C G$, although there was no difference in total digestible nutrients between BR (54.6\%) and CG (54.5\%).

\section{Preference of animals}

Feeding condition under indoor housing environment (e.g. the number of cattle, hays, amount of feeding and feeding time schedule) often differs to that in grazing grassland. For example, the number of cow in a barn influences the presence of leader cow (under small- or large-scale group feeding) or absence of leader cow (under individual feeding). In this study, each cattle was placed in separated room to exclude the factor of the number of cattle. Table 3 summarized the number of switching by cattle between BR and CG in the first half 15 minutes and the second half 15 minutes. The value of experiments 1 and 3 in the second half 15 minutes seemed to be relatively higher than that of the first half 15 minutes. On the other hand, the experiment 2 tended the opposite to the experiments 1 and 3. Though

Table 1. Agronomic traits and dry matter yield of BR (Brachiaria ruziziensis, tetraploid strain) and CG (Cloris gayana) for 1st cutting

\begin{tabular}{lcccccccc}
\hline $\begin{array}{c}\text { Grass } \\
\text { species }\end{array}$ & $\begin{array}{c}\text { Plant length } \\
(\mathbf{c m})\end{array}$ & $\begin{array}{c}\text { Stem } \\
\text { diameter }(\mathbf{c m})\end{array}$ & $\begin{array}{c}\text { Leaf blade } \\
\text { width }(\mathbf{c m})\end{array}$ & $\begin{array}{c}\text { Leaf blade } \\
\text { length }(\mathbf{c m})\end{array}$ & $\begin{array}{c}\text { Fresh matter } \\
\text { yield }(\mathbf{t} / \mathrm{ha})\end{array}$ & $\begin{array}{c}\text { Dry matter } \\
(\%)\end{array}$ & $\begin{array}{c}\text { Dry matter } \\
\text { yield }(\mathbf{t} / \text { ha) }\end{array}$ & $\begin{array}{c}\text { The ratio of the leaf } \\
\text { blade weight against } \\
\text { whole plant }(\%)\end{array}$ \\
\hline BR & $116.3^{\mathrm{b}}$ & $4.2^{\mathrm{a}}$ & $2.3^{\mathrm{a}}$ & $36.6^{\mathrm{b}}$ & $3,717^{\mathrm{a}}$ & $19^{\mathrm{b}}$ & 593 & $37.8^{\mathrm{b}}$ \\
$\mathrm{CG}$ & $126.6^{\mathrm{a}}$ & $3.6^{\mathrm{b}}$ & $0.9^{\mathrm{b}}$ & $58.2^{\mathrm{a}}$ & $2,583^{\mathrm{b}}$ & $24^{\mathrm{a}}$ & 605 & $43.8^{\mathrm{a}}$ \\
\hline
\end{tabular}

a,b Values followed by different superscript letters within each column differ significantly $(p<0.05)$ by t-test.

Table 2. Chemical composition of three forage grasses and concentrates feed

\begin{tabular}{|c|c|c|c|c|c|c|c|c|c|}
\hline Feeds & CP (DM \%) & NDICP (CP \%) & NDF (DM \%) & ADF (DM \%) & ADL (DM \%) & Ash (DM \%) & $\mathrm{EE}(\mathrm{DM} \%)$ & NFC (DM \%) & TDN (DM \%) \\
\hline BR & $12.2^{\mathrm{a}}$ & $29.1^{b}$ & $63.0^{b}$ & $35.1^{b}$ & 4.2 & $11.9^{\mathrm{a}}$ & 2.0 & $14.5^{\mathrm{a}}$ & 54.6 \\
\hline$C G$ & $10.5^{b}$ & $43.3^{\mathrm{a}}$ & $69.6^{a}$ & $38.8^{\mathrm{a}}$ & 4.2 & $10.2^{b}$ & 2.2 & $12.0^{b}$ & 54.5 \\
\hline PM & 11.2 & 40.4 & 70.6 & 39.6 & 4.1 & 10.3 & 2.0 & 10.4 & 54.3 \\
\hline (oncentrates ${ }^{1)}$ & 21.2 & - & - & - & - & 6.3 & 2.7 & - & 75.0 \\
\hline
\end{tabular}

CP, crude protein between BR (Brachiaria ruziziensis, tetraploid strain) and CG (Cloris gayana); DM, dry matter; NDICP, neutral detergent insoluble protein; NDF, neutral detergent fiber; ADF, acid detergent fiber; ADL, acid detergent lignin; EE, ether extract; NFC, non-fibrous carbohydrate; TDN, total digestible nutrients; PM (Panicum maximum), Guinea.

1) The concentrates feed contained maize, wheat bran, soybean meal, dicalcium phosphate, salt and feed additives.

$a, b$ Values followed by different superscript letters differ significantly $(p<0.05)$ by t-test. 
Table 3. Switches by cattle between BR (Brachiaria ruziziensis, tetraploid strain) and CG (Cloris gayana) under indoor housing condition

\begin{tabular}{|c|c|c|c|c|c|c|c|c|c|c|c|c|}
\hline \multirow{2}{*}{$\begin{array}{c}\text { Number of visiting } \\
\text { to BR plot }\end{array}$} & \multicolumn{4}{|c|}{ Experiment 1} & \multicolumn{4}{|c|}{ Experiment 2} & \multicolumn{4}{|c|}{ Experiment 3} \\
\hline & $1 \mathrm{~d}$ & $2 d$ & $3 \mathrm{~d}$ & $4 \mathrm{~d}$ & $1 \mathrm{~d}$ & $2 d$ & $3 d$ & $4 \mathrm{~d}$ & $1 \mathrm{~d}$ & $2 d$ & $3 d$ & $4 \mathrm{~d}$ \\
\hline Times/0-15 min & $2.8(0.9)$ & $2.0(0.7)$ & $2.3(0.8)$ & $1.3(0.5)$ & $5.3(1.4)$ & $6.5(1.8)$ & $2.3(0.8)$ & $9.0(2.6)$ & $3.3(0.6)$ & $2.8(1.0)$ & $2.0(0.6)$ & $2.5(1.3)$ \\
\hline
\end{tabular}

Figures in parentheses represent standard error (SE).

the number of switches in the first half 15 minutes varied with the different experiments, in over all, it tended to decrease as the experiment days passed.

The chronological changes for the proportion of time spent grazing BR and CG are shown in Figure 2. The cattle in experiment 2 tended to prefer BR over CG in the first half 15 minutes in second $(\mathrm{p}<0.05)$, third $(\mathrm{p}<0.01)$ and fourth $(\mathrm{p}<0.01)$ experimental days. The preferences of cattle in experiments
1 and 3 for BR were also tended to be higher than CG, although it was not significant ( $\mathrm{p}>0.05)$. In the second half 15 minutes, the cattle in all experiments tended to prefer CG over $B R$. There were no significant differences on preference between animals grazed BR and CG in whole experimental time (30 minutes).

The chronological changes for the proportion of grazing amount of BR and CG are shown in Figure 3. In the first half

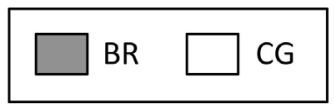

\section{Experiment 1}
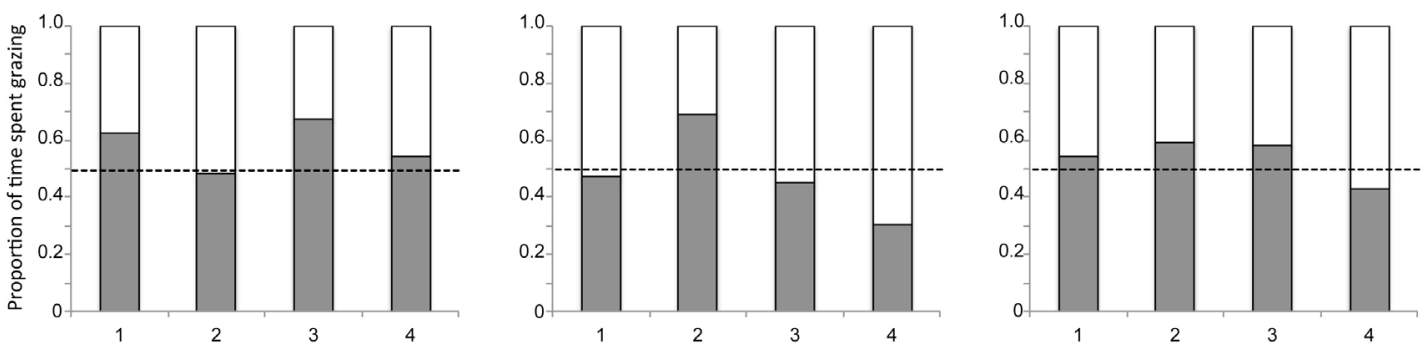

Experiment 2
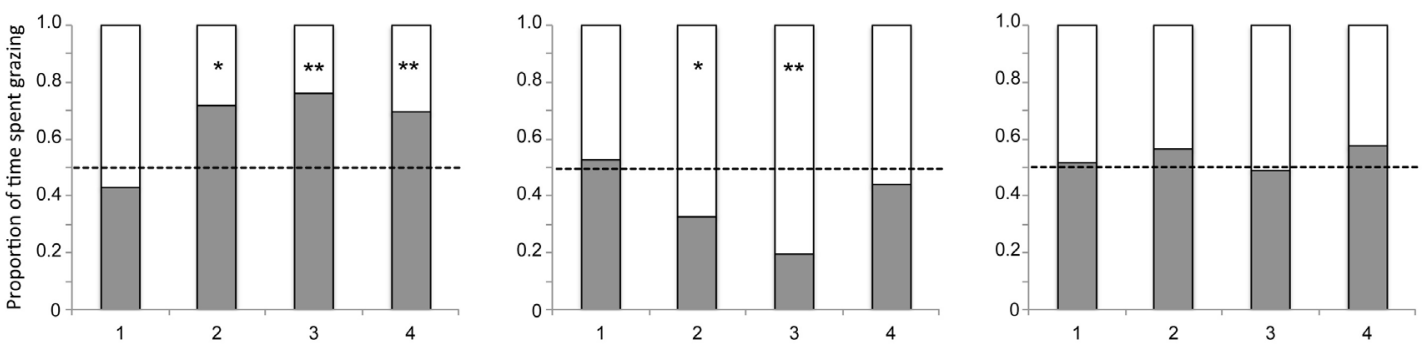

Experiment 3
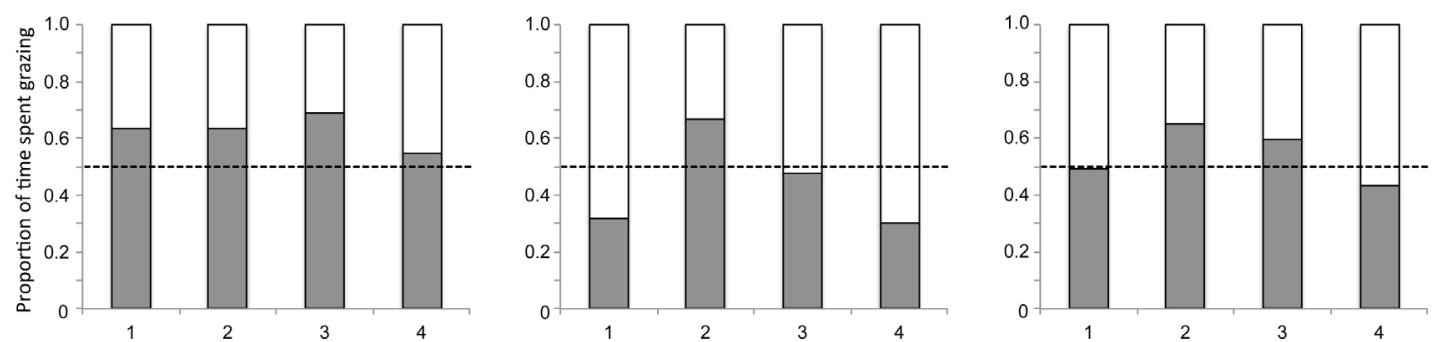

Figure 2. The chronological change for the proportion of time spent grazing ruzigrass tetraploid strain (BR, open columns) hay and Rhodes grass (CG, hatched columns) hay by cattle. The broken lines indicate the proportion of the amount of hay fed with the two grasses (BR:CG $=0.5: 0.5)$. * Indicates a significant bias from the hay fed proportion at $\mathrm{p}<0.05$. BR, Brachiaria ruziziensis; $\mathrm{CG}$, Cloris gayana. 


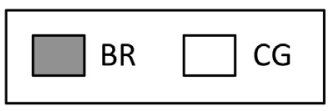

Experiment 1
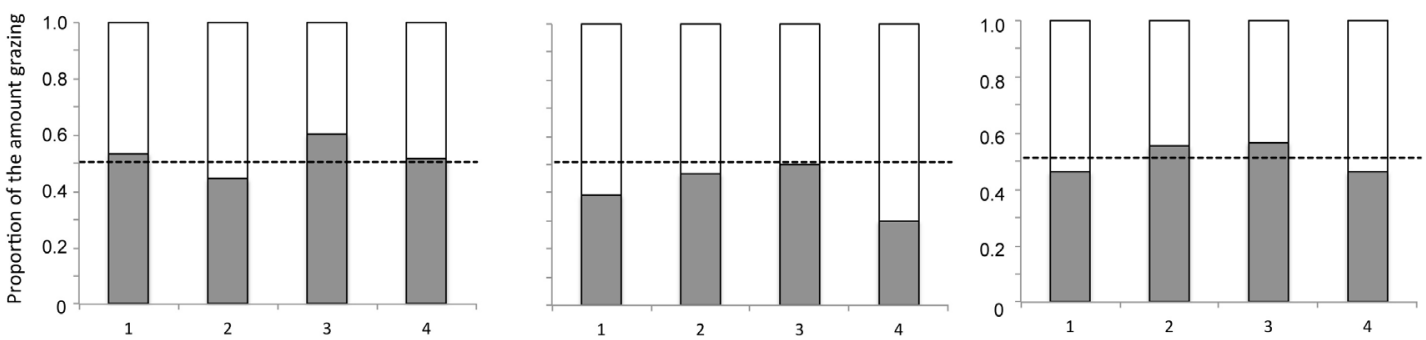

Experiment 2
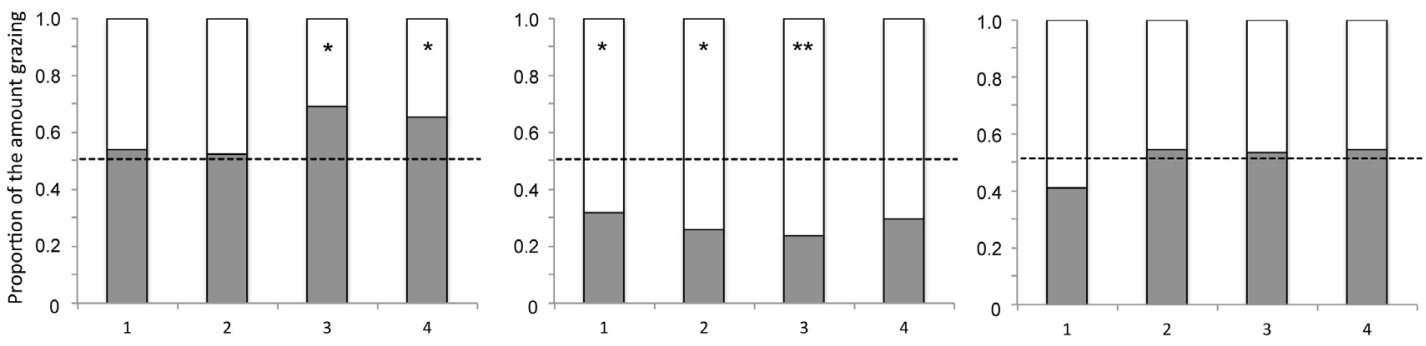

Experiment 3
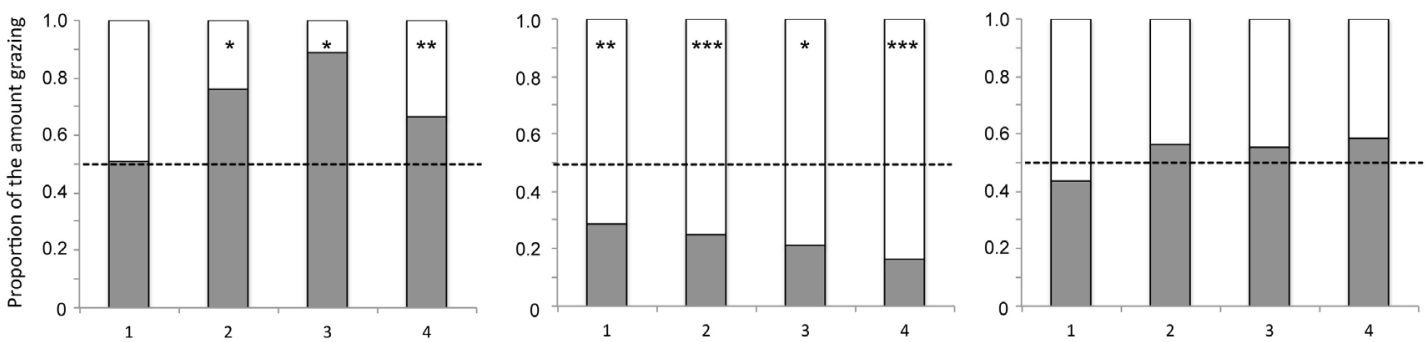

Figure 3. The chronological change for the proportion of grazing amount of ruzigrass tetraploid strain (BR, open columns) hay and Rhodes grass (CG, hatched columns) hay by cattle. The broken lines indicate the proportion of the amount of hay fed with the two grasses (BR:CG = 0.5:0.5). * Indicates a significant bias from the hay fed proportion at $\mathrm{p}<0.05$. BR, Brachiaria ruziziensis; $\mathrm{CG}$, Cloris gayana.

15 minutes, the proportion of grazing amount of BR was equally or significantly higher than the proportion of grazing amount of CG in experiments 2 and 3. The experiment 1 did not show the biased proportion during the whole experimental period. On the other hand, in experiments 2 and 3, the proportion of grazing amount of CG was significantly $(\mathrm{p}<0.05)$ higher than the proportion of grazing amount of BR. These results of short-term grazing behavior between BR and CG (the decrease of switches and the increase of proportion time and amount of grazing in $\mathrm{BR}$ ) indicated that the preference became stronger after when the experiment started.

Previous studies reported that the similar trends were observed in the both of preference and voluntary intake investigation, the trend might be influenced by many factors such as the $\mathrm{CP}$ content [13], the ratio of leaf part [14,15], digestibility [16] and the soluble carbohydrate content [17]. In the present study, BR was superior to CG in some chemical compositions such as protein, fibers (NDF and ADF) and NFC, which might work as positive factor for the preference by cattle. Several researches have been reported that the positive correlation was found between the amount of carbohydrate (or sugar) and the amount of voluntary intake in some temperate grasses such as orchard grass [18] and tall fescue [19]. As another related research, the order of palatability for horse almost corresponded to the order of the amount in NFC [20].

The $\mathrm{CP}$ content is also one of factors for influencing the microbial activity in the rumen. Especially, the content of NDCIP between BR and CG were different strikingly. The NDCIP is the protein-polymerized fiber (cellulose, hemicellulose and lignin) which can be digested slowly. The insufficient amount of available $\mathrm{CP}$ for the microbe in the rumen would make the activity of microbe in the rumen slowly, resulting the low voluntary intake with the case of high CF content feed. Another previous study reported that facing quantitative and 
Table 4. Relationship between time spent BR (Brachiaria ruziziensis) in the first half 15 minutes and age in days of cattle

\begin{tabular}{lcccc}
\hline \multirow{2}{*}{ Variable } & \multicolumn{4}{c}{ Experiment day } \\
\cline { 2 - 5 } & $\mathbf{1} \mathbf{d}$ & $\mathbf{2} \mathbf{d}$ & $\mathbf{3} \mathbf{d}$ & $\mathbf{4} \mathbf{d}$ \\
\hline Whole animals & $0.489(0.196)$ & $0.397(0.201)$ & $-0.364(0.244)$ & $0.180(0.577)$ \\
Male & $0.617(0.192)$ & $-0.05(0.924)$ & $-0.09(0.924)$ & $-0.20(0.705)$ \\
Female & $0.248(0.640)$ & $0.913^{* *}(0.01)$ & $-0.763(0.08)$ & $0.531(0.279)$ \\
\hline
\end{tabular}

Figures in parentheses represent probability. Correlation with ** is significant at $p<0.0$.

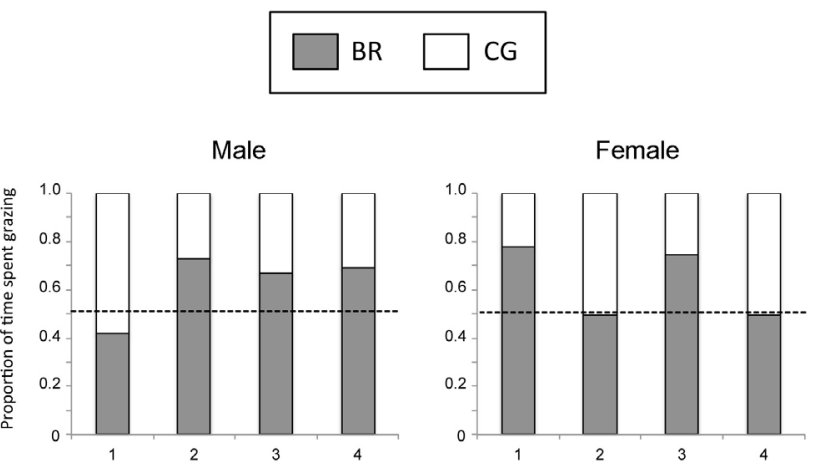

Figure 4. The chronological change for the proportion of time spent grazing ruzigrass tetraploid strain (BR, open columns) hay and Rhodes grass (CG, hatched columns) hay expressed by sex. The broken lines indicate the proportion of the amount of hay fed with the two grasses (BR:CG $=0.5: 0.5$ ). There was no significant bias between $B R$ and CG. BR, Brachiaria ruziziensis; CG, Cloris gayana.

qualitative patchiness in vegetation, animals were sensitive to protein concentration in the diet and perceived protein intake as a currency for patch selection [13]. The similar trends were observed under indoor housing environment in this study, and the result might made it evident that cattle were sensitive to protein concentration in diet. Also, preference of cattle was influenced by the sense of taste rather than other senses [21].

The present study showed that cattle tended to prefer BR over CG in the first half 15 minutes although the cattle had no experience to grazing BR. Over all, in this study, cattle exhibited high potential to respond to novel object named as neophilia. Neophilia is animal behavior that is an animal's interest or liking of a novel object. Many researches related with neophilia and neophobia have been conducted in animals such as rat [22], dogs [23] and apes [24,25]. Previous research reported that the responses were unrelated to sex, but immatures showed more object exploration than adults in wild chacma baboons (Papio ursinus) and geladas (Theropithecus gelada) [24]. In this study, the trend of chronological change for the proportion of time spent grazing BR and CG differed by sex though it was not significant (Figure 4). The average age of experimental cattle were $346 \pm 16$ day-old (mean $\pm S E$ ), there were no significant relationship between the time spent grazing BR and age in days of cattle except second day in female cattle (Table 4). These results indicated that the preference of Japanese black cattle at growing stage might not be influenced by sex and age. However, in middle and end fattening phase, the limiting vitamin A feeding frequently induced the vitamin
A deficiencies of cows, one of serious symptom is blindness [26]. Under the ocular deterioration, the information about the relationship between preference and olfaction should be more important and investigated for cattle preference.

Thus, it is possible to conclude that BR was superior to CG in some chemical compositions such as protein, fibers (NDF and $\mathrm{ADF}$ ) and NFC, and the approach for assessment for grazing behavior in early age could clarify that these advantages might work as positive factor for the preference by cattle at growing age. Additionally, cattle at growing age exhibited neophilia for BR bred newly. Therefore, the approach can be applied for one of criteria to evaluate the preference of Japanese black cattle at early age for newly introduced or bred grasses or cultivars under indoor housing environment. A further study of the contributing factor for the preference of cattle in early age, and the relationship between the preference and the voluntary intake should be conducted.

\section{CONFLICT OF INTEREST}

We certify that there is no conflict of interest with any financial organization regarding the material discussed in the manuscript.

\section{ACKNOWLEDGMENTS}

This study was performed under a financially support by Comprehensive Project To Create Strategic Variety of Okinawa 
Typed Grass for Expanding Beef Cattle Production project of Okinawa prefecture. We also would like to express my gratitude to Ms. Kaori Kouki for providing plant material "OKI-1", and Mr. Koichiro Hemmi, Mr Yusei Yamashita for their technical support and management of experimental plots and animals in this study.

\section{REFERENCES}

1. Hanagasaki K, Mochizuki T, Morikawa N, Nagatoshi M, Toma T. Investigation for selection new tropical forage cultivars adapted with Okinawa. (1) Comparison of digestible dry matter yield and crude protein content. Annual Report Okinawa Prefectural Livestock and Grassland Research Center (in Japanese). 2008;44:79-84.

2. Valle CB, Savidan YH. Genetics, cytogenetics and reproductive biology of Brachiaria. In: Miles JW, Maass BL, Valle CB. editors. Brachiaria; Biology, Agronomy and Improvement. Cali, Colombia. CIAT; 1996. pp. 147-63.

3. Ishigaki G, Gondo T, Suenaga K, Akashi R. Induction of tetraploid ruzigrass (Brachiaria ruziziensis) plants by colchicines treatment of in vitro multiple-shoot clumps and seedlings. Grassl Sci 2009;55:164-70.

4. Kouki K, Ishigaki G, Akashi R, Shimabukuro H. The newlybred cultivar production in Brachiaria grass. (1) Production of the high seed yield strains using sexual tetraploid ruzigrass 'Miyaokikoku-ichigou'. Annual Report Okinawa Prefectural Livestock and Grassland Research Center (in Japanese) 2014; 52:73-5.

5. Fukagawa S, Hori M, Iwanaga T, Sakita S, Ishii Y. Relationship between palatability and feed compositions of first-cut hay in tropical grasses. West Japan J Anim Sci 2003;46:39-45.

6. Kondo S, Maeda T, Nishino S, Asahida Y. Relationships among voluntary intake, eating rate and palatability of forage in sheep. Japanese Livest Manage 1988;24:57-61.

7. Licitra G, Mernandez TM, Van Soest JP. Standardization of procedures for nitrogen fractionation of ruminant feeds. Anim Feed Sci Technol 1996;57:347-562.

8. AOAC. Official Method of Analysis of AOAC International. 14th ed. Washington, DC: AOAC International; 1984.

9. Goering HK, Van Soest PJ. Forage Fiber Analyses (apparatus, reagents, procedures, and some applications). Agriculture Handbook No. 379. Washington, DC, USA: Agricultural Research Service, US Department of Agriculture; 1970.

10. Claringbold JJ, Biggers JD, Emmens CW. The angular transformation in quantal analysis. Biometrics 1953;9:467-84.

11. R Core Team. R: A language and environment for statistical computing. Vienna, Austria: R Foundation for Statistical Computing; 2014.

12. Baumont R. Palatability and feeding behaviour in ruminants. Ann Zootech 1996;45:385-400.

13. Hirata M, Murakami K, Ikeda K, Oka K, Tobisa M. Cattle use protein as a currency in patch choice on tropical grass swards. Livest Sci 2012;150:209-19.

14. McLeod MN, Smith BR. Eating and ruminating behaviour in cattle given forage differing in fiber content. Anim Prod 1989; 48:503-11.

15. McLeod MN, Kennedy PM, Minson DJ. Resistance of leaf and stem fractions of tropical forage to chewing and passage in cattle. Br J Nutr 1990;63:105-19.

16. Minson DJ. Digestibility and voluntary intake by sheep of five Digitaria species. Australian J Exp Agric Anim Husb 1984;24: 494-500.

17. Saiga S. Differences in intake among grass species and cultivars, and factors influencing them. Japanese Soc Grassl Sci 1990;36: 60-6.

18. Cowlishaw JR, Alder FE. The grazing preferences of cattle and sheep. J Agric Sci 1960;54:257-65.

19. Buckner RC, Todd JR, Burrus PB, Barnes RF. Chemical composition, palatability, and digestibility of ryegrass-tall fescue hybrids, "Kenwell" and "Kentuchy 31" tall fescue varieties. Agron J 1967;59:345-9.

20. Rogalski M. Testing the palatability of pasture sward for horses on the basis of comparative grazing intensity unit. Rocznili Akademii Rolniczej w Poznaniu. 1982;138:85-92.

21. Krueger WC, Laycock WA, Price DA. Relationships of taste, smell, sight, and touch to forage selection. J Range Manage 1974;27:258-62.

22. Stephen FD, Scott AB, Thompson AM. Exposure to a proteinand tryptophan-deficient diet results in neophilia. Bull Psychon Soc 1993;31:213-6.

23. Kaulfuss P, Mills DS. Neophilia in domestic dogs (Canis familiaris) and its implication for studies of dog cognition. Anim Cogn 2008;11:553-6.

24. Bergman TJ, Kitchen DM. Comparing responses to novel objects in wild baboons (Papio ursinus) and geladas (Theropithecus gelada). Anim Cogn 2009;12:63-73.

25. Gustafsson E, Jalme MS, Bomsel MC, Krief S. Food neophobia and social learning opportunities in great apes. Int J Primatol 2014;35:1037-71.

26. Barnett KC, Palmer AC, Abrams JT, Spratling FR, Sharman IM. Ocular changes associated with hypovitaminosis A in cattle. Br Vet J 1970;126:561-73. 